\title{
Dietary Steroid
}

National Cancer Institute

\section{Source}

National Cancer Institute. Dietary Steroid. NCI Thesaurus. Code C68341.

Any substance found in the diet, comprising a terpenoid characterized by a conjug ated carbon structure of four rings: three cyclohexane rings and one cyclopentane ring. Individual steroids vary by the functional groups attached to these rings and by the oxidation state of the rings. 